Article

\title{
Fundamentals of Ornamental Plants in Removing Benzene in Indoor Air
}

\author{
Yu Gong ${ }^{1,2} \mathbb{D}^{\mathbb{D}}$, Tao Zhou ${ }^{1}$, Peiran Wang ${ }^{1}$, Yinuo Lin ${ }^{1}$, Ruomeng Zheng ${ }^{1}$, Youcai Zhao ${ }^{1}$ and \\ $\operatorname{Bin} \mathrm{Xu}^{1,3, * \mathbb{D}}$ \\ 1 State Key Laboratory of Pollution Control and Resource Reuse, College of Environmental Science and \\ Engineering, Tongji University, Shanghai 200092, China; ygong@mun.ca (Y.G.); \\ zhou410218380@163.com (T.Z.); 1551430@tongji.edu.cn (P.W.); 1551455@tongji.edu.cn (Y.L.); \\ 1551440@tongji.edu.cn (R.Z.); zhaoyoucai@tongji.edu.cn (Y.Z.) \\ 2 Sustainable Resource Management, Grenfell Campus, Memorial University of Newfoundland, 20 University \\ Drive, Corner Brook, NL A2H 5G4, Canada \\ 3 Shanghai Institute of Pollution Control and Ecological Security, Shanghai 200092, China \\ * Correspondence: binxu@tongji.edu.cn; Tel.: +86-13916186347; Fax: +86-21-65981831
}

Received: 2 April 2019; Accepted: 22 April 2019; Published: 24 April 2019

\begin{abstract}
The concentration of benzene in indoor air has received appreciable attention due to its adverse health effects. Although phytoremediation has been considered as an eco-friendly method to remove benzene, it is unclear how to select plants with a high removal rate. In this study, we evaluated the benzene removal efficiency of four common ornamental plants, Epipremnum aureum, Chlorophytum comosum, Hedera helix and Echinopsis tubiflora, and we also explored the factors impacting benzene removal efficiency. The removal efficiency of all plants in this study averaged at 72 percent. The benzene absorption rates of Epipremnum aureum, Hedera helix and Chlorophytum comosum were 1.10, 0.85 and $0.27 \mu \mathrm{g} \cdot \mathrm{m}^{-3} \cdot \mathrm{cm}^{-2}$, respectively. This is due to the different transpiration rates and chlorophyll concentrations in the plants. The benzene removal efficiency of crassulacean acid metabolism plant (Echinopsis tubiflora) was 23\% higher than C3 plant (Epipremnum aureum) under dark conditions. This can be attributed to the fact that the characteristic of Echinopsis tubiflora stomata is different from Epipremnum aureum stomata, which is still open under dark conditions. Therefore, Echinopsis tubiflora can take up more benzene than Epipremnum aureum. For different initial benzene concentrations, the benzene removal efficiency of Echinopsis tubiflora was always great (50-80\%), owing to its high rate of transpiration and concentration of chlorophyll. Our findings indicate that transpiration rate and chlorophyll concentration can be used as reference parameters to facilitate ornamental plant screening for indoor air quality improvement.
\end{abstract}

Keywords: Phytoremediation; benzene; ornamental plants; indoor air quality

\section{Introduction}

Benzene exposure has received appreciable attention due to its adverse health effects. Even a low level of benzene exposure can lead to leukemia, aplastic anemia and some cancers [1,2]. Emissions from painting or furniture are considered to be an important source of benzene in the indoor environment. Given that people spend more than $80 \%$ of their time indoors [3], it is essential to study the effective measures of removing benzene from the indoor air.

Indoor air quality can be improved by many air purification techniques, including adsorption, photolysis and photocatalysis [4]. Each technique has its own disadvantages, such as high operating costs or the production of secondary pollutants [4,5]. To avoid these disadvantages, phytoremediation has been proposed as an eco-friendly alternative technique for the treatment of indoor air pollutants [6-9]. 
Furthermore, in order to accurately assess the VOC removal efficiency of plants, the traditional method of the test chamber has been improved [10], and a great deal of research has been conducted. Most of these research has focused on treating benzene in indoor air by $\mathrm{C} 3$ plants and has found that they have potential to improve indoor air quality [11-15]. However, few studies have focused on the benzene removal efficiency of crassulacean acid metabolism (CAM) plants [16], which is a type of effective phytoremediation plant and a common ornamental plant in indoor environments. Noticeably, the concentrations used in these tests were several orders of magnitude greater that those in real-life homes. We cannot simply extrapolate the results from chamber experiments to real-life homes due to the great differences between them, such as in terms of their air temperature, humidity and ventilation. In order to fill this knowledge gap, Wood et al. [17] conducted an experiment in real-life homes and did not find the phenomenon of the removal of VOCs by plants due to low VOC concentrations. This result indicates a threshold value for VOC removal by plants. However, the threshold value is still unknown. Moreover, it is also unclear whether other factors affect the ability of plants to remove VOCs in real-life homes.

Many factors impact the VOC removal efficiency of plants. Previous studies have indicated that light condition is an important factor for phytoremediation $[18,19]$. Some studies have reported that plant-associated microorganisms play an important role in removing indoor air pollutants [20,21]. Sriprapat and Thiravetyan [18] reported that water stress has a negative effect on phytoremediation. Furthermore, chlorophyll concentration and enzyme systems are reported to be essential for plants in detoxifying hazardous organic compounds [18,22]. However, systematical analysis of influencing factors such as chlorophyll or peroxidase (POD) is scarce. More importantly, there is still no guidance on how to screen plants to improve indoor air quality.

The objective of this study was to investigate the mechanism and capacity of CAM and C3 plants of removing benzene in indoor air. The factors influencing the benzene removal efficiency of plants were studied, including the plant species, light conditions, concentration of benzene, rate of transpiration, concentration of chlorophyll and activity of POD. The result of the present study can be used as a guidance for screening appropriate plants to improve the indoor air quality, particularly in terms of removing benzene.

\section{Materials and Methods}

\subsection{Plant Cultured Condition}

Epipremnum aureum, Chlorophytum comosum, Hedera helix and Echinopsis tubiflora were purchased from one ornamental plant shop in Shanghai, China. All plants were thoroughly cleaned with taps and distilled water to disperse soil particles which adhered to plant leaves. The leaf area of experimental plants was measured by a leaf area meter (YMJ-B, Top Instrument Inc., Hangzhou, China) and controlled by judicious pruning. Those plants were maintained in plastic pots, which contained $300 \mathrm{~g}$ of soil as a growth media. Furthermore, the lower part of the plant, including soil, was covered by four layers of plastic film to avoid the effect of other factors, such as soil and pot absorption of benzene.

\subsection{Fumigation Chamber}

Glass desiccators with a volume of $0.216 \mathrm{~m}^{3}$ were built for plant fumigation. Three replicate chambers (plant + benzene) and one controlled chamber (only plant) were used in each treatment. There were two separate ports: an injection port and a sampling port. After plants were placed into each chamber, the chamber was closed and water sealed. Then, $99.9 \%$ benzene (100 ppm, Weichuang Inc., Shenzhen, China) was injected into the chamber at $200 \mathrm{~mL} \cdot \mathrm{min}^{-1}$ for $120 \mathrm{~s}$, regulated by a separate mass flow meter (MF4008, Siargo Inc., Santa Clara, CA, USA). The mass flow meter was calibrated before use. Experiments were conducted in a controlled laboratory with a temperature of $22.3^{\circ} \mathrm{C}$ and relative humidity of $60.5 \%$. 
A portable pump (TWA-300XB, XBXY Inc., Beijing, China) and stainless-steel tubes filled with Tenax TA (N9307005, PerkinElmer Inc., American Fork, UT, USA) were used for sampling gas from the chambers after $12,24,48$, and $72 \mathrm{~h}$ of fumigation. Before sampling, all the Tenax TA tubes were conditioned in helium for $2 \mathrm{~h}$ at $225^{\circ} \mathrm{C}$. The flow rate of the pump was set at $0.2 \mathrm{~L} \cdot \mathrm{min}^{-1}$, as calibrated by a gas flow meter (Model 4050, TSI Inc., Minnesota, USA). The sampling volume was calculated using the following equation:

$$
\mathrm{V}_{s}=\mathrm{Q}_{a} t \times \frac{293.15}{273.15+T} \times \frac{P}{101.325}
$$

where $\mathrm{V}_{s}$ is the standard sampling volume (L); Qa is the actual flow rate (litres.min ${ }^{-1}$ ) measured by the flow meter; $\mathrm{t}$ is the sampling time $(\mathrm{min})$; and $\mathrm{T}$ and $\mathrm{P}$ are the ambient temperature $\left({ }^{\circ} \mathrm{C}\right)$ and the barometric pressure $(\mathrm{kPa})$, respectively. After sample collection, chambers were evacuated and prepared to test the next species. The same sampling procedure was applied for each species.

\subsection{Removal of Benzene in House}

In order to compare the benzene removal efficiency in chambers, Epipremnum aureum was placed in a house which was painted in a week, and benzene was measured. Portable pump (TWA-300XB, XBXY Inc., Beijing, China) and stainless-steel tubes filled with Tenax TA (N9307005, PerkinElmer Inc., American Fork, UT, USA) were used for gas sampling after 0, 2, 7, 14 and 35 days. The concentration of benzene was measured by gas chromatography.

\subsection{Transpiration Rate, POD and Chlorophyll Concentration Analysis}

The rate of transpiration was measured by the weighing method [23]. Three leaves were cut off the plant before and after fumigation. Then, each leaf was weighed by electronic analysis balance (BSA224S, Sartorius Inc. Göttingen, Germany) before and after $10 \mathrm{~min}$ of air drying treatment at room temperature. The weight difference of the leaf divided by the leaf area was used to represent the transpiration rate.

The activity of POD in each plant was measured by a UV-visible spectrophotometer (UV-1700, SHIMADZU Inc., Kyoto, Japan) at $470 \mathrm{~nm}$. Ten minutes of dark adaptation was required. The leaves were dissolved in $10 \mathrm{~mL}$ phosphoric acid buffer solution $\left(20 \mathrm{mmol} \cdot \mathrm{L}^{-1}\right)$. Then, they were centrifuged for $20 \mathrm{~min}$ with $5000 \mathrm{r} \cdot \mathrm{min}^{-1}$ in a centrifuge machine (TDL-5-A, Anting Inc., Shanghai, China). The supernatant fraction was prepared as extract enzyme solution. A cuvette with $3 \mathrm{~mL}$ reaction mixed solution ( $50 \mathrm{~mL}$ phosphoric acid buffer solution, $28 \mu \mathrm{L}$ guaiacol and $19 \mu \mathrm{L} 30 \% \mathrm{H}_{2} \mathrm{O}_{2}$ ), $1 \mathrm{~mL}$ phosphoric acid buffer solution $\left(20 \mathrm{mmol} \cdot \mathrm{L}^{-1}\right)$ and $1 \mathrm{~mL}$ extract enzyme solution was used to measure the absorbance. The data were recorded every $30 \mathrm{~s}$, and the variation of absorbance in 1 min was used to indicate the enzyme activity. POD was calculated by the following equation:

$$
\mathrm{K}=\frac{\Delta A 470 \times V_{t}}{W \times V_{s} \times 0.01 \times t}
$$

where $\mathrm{K}$ is the activity of POD $\left(\mathrm{U} \cdot(\mathrm{g} \cdot \mathrm{min})^{-1}\right) ; \Delta A 470$ : absorbance difference during reacting time $(t)$; $W$ is the fresh weight of plants $(\mathrm{g})$; $\mathrm{Vt}$ is the total volume of extract enzyme solution $(\mathrm{mL})$; $\mathrm{Vs}$ is the volume of extract enzyme solution for measurement $(\mathrm{mL})$; and $\mathrm{t}$ is the reaction time $(\mathrm{min})$.

Chlorophyll in each plant was measured by a UV-visible spectrophotometer (UV-1700, SHIMADZU Inc., Kyoto, Japan) at $663.6 \mathrm{~nm}$ and $646.6 \mathrm{~nm}$. Five leaves of each species and $10 \mathrm{~min}$ dark adaptation were required. The leaves were cut into pieces and solved in tubes with $80 \%$ acetone and $95 \%$ ethanol (2:1). The tube was then put in thermostatic water bath pot (HH-4, Guohua Instrument Inc., Changzhou, China) at $60^{\circ} \mathrm{C}$ for $10 \mathrm{~min}$. Then, the supernatant fraction was used to measure chlorophyll in the plant leaf. 


\subsection{Benzene Removal Efficiency}

In order to compare the benzene removal efficiency of plants in the chamber and real environment, we chose a renovated house to test for one month. Given the volume of the house, 16 potted Epipremnum aureum plants were selected for the real environment test. The removal efficiency of benzene was evaluated using the initial and final benzene concentrations in the chamber and renovated house, respectively. The amount of gas removed per unit surface area of plant leaf and the percentage of removal efficiency were calculated as

$$
\begin{gathered}
\mathrm{M}=\frac{C_{i}-C_{f}}{C_{i}} \times 100 \\
\mathrm{~N}=\frac{C_{i}-C_{f}}{A}
\end{gathered}
$$

where $\mathrm{M}$ is the removal efficiency $(\%)$; $\mathrm{N}$ is the benzene removal rate $\left(\mathrm{mg} \cdot \mathrm{m}^{-3} \cdot \mathrm{cm}^{-2}\right)$; $\mathrm{C}$ is the initial concentration $\left(\mathrm{mg} \cdot \mathrm{m}^{-3}\right)$; Cf is the final concentration of benzene $\left(\mathrm{mg} \cdot \mathrm{m}^{-3}\right)$; and A is the total leaf area $\left(\mathrm{cm}^{2}\right)$.

\subsection{Effect of Light Conditions}

The C3 plant (Epipremnum aureum) and the crassulacean acid metabolism (CAM) plant (Echinopsis tubiflora) were selected in this measurement. In the light condition, plants were exposed to $24 \mathrm{~h}$ of lamplight, while in the dark condition, black plastic bags were used to cover the chambers to create $24 \mathrm{~h}$ of darkness. In normal conditions, plants were exposed to $12 \mathrm{~h}$ of the light condition and $12 \mathrm{~h}$ of the dark condition. Benzene in the chambers was collected, and then the concentration was measured by gas chromatography. Rate of transpiration, activity of POD and concentration of chlorophyll were also measured before and after the experiment.

\subsection{Effect of Different Benzene Concentrations}

With the purpose of detecting the benzene removal efficiency of plants at low and high concentrations, respectively, we conducted the experiment at two different initial benzene concentrations of 0.2 and $50 \mathrm{ppm}$. Plant preparation, fumigation, and experimental conditions were performed as mentioned above.

\subsection{Gas Analysis}

Analysis of benzene samples from adsorbent tubes was performed by thermal desorption (TurboMatrix 350 ATD, Perkin-Elmer Inc., American Fork, UT, US) and gas chromatography/mass spectrometry (GC/MS) (GC/MS, DSQ-II, Thermo Fisher, Waltham, MA, USA). A DB-5MS capillary column $(30 \mathrm{~m} \times 0.25 \mathrm{~mm} \times 0.25 \mu \mathrm{m}$, Agilent Inc., Santa Clara, CA, USA) was used on the GC and helium was used as the carrier gas. The oven temperature of the GC was initially held at $40^{\circ} \mathrm{C}$ for 3 min and then raised to $60^{\circ} \mathrm{C}$ at $2{ }^{\circ} \mathrm{C} \cdot \mathrm{min}^{-1}$ and to $250{ }^{\circ} \mathrm{C}$ at $20^{\circ} \mathrm{C} \cdot \mathrm{min}^{-1}$, and finally kept at $250{ }^{\circ} \mathrm{C}$ for $3 \mathrm{~min}$. The mass spectrometer was operated in the electron impact mode $(70 \mathrm{eV})$ by a full scanning between 35 and 350 mass units. The method detection limit (MDL) of benzene was $0.5 \mu \mathrm{g} \cdot \mathrm{m}^{-3}$.

\subsection{Statistical Analysis}

The one-way analysis of variance and Duncan's multiple range tests were used (1) to measure the difference of benzene removal efficiency, chlorophyll concentration, POD and transpiration rate of different plants at different times; (2) to measure the difference of the benzene removal efficiency of Echinopsis tubiflora, and Epipremnum aureum under different light conditions; and (3) to measure the difference of the benzene removal efficiency of the four plants after being exposed to different benzene concentrations. A Pearson correlation analysis was conducted to investigate the relationship 
between the chlorophyll concentration, transpiration rate and POD activity, and benzene removal rate in different plants. The data were statistically analyzed using SPSS version 20.

\section{Results and Discussions}

\subsection{Benzene Removal Efficiency of Experimental Plants}

Ornamental potted plants (Epipremnum aureum) were placed in the renovated house and chamber to remove benzene. As shown in Figure 1a, the decreasing trend of benzene concentration in the test house was more pronounced than that in the control house. The result is in agreement with the previous finding, where VOCs in a real-life house may be absorbed by plants [24]. This was further verified in Figure $1 \mathrm{~b}$. After $72 \mathrm{~h}$ of fumigation, the plant could take up a total of $84.1 \%$ benzene. The different benzene removal efficiencies of Epipremnum aureum between the chamber and house can be attributed to the low initial concentration of benzene in the real-life house [17].

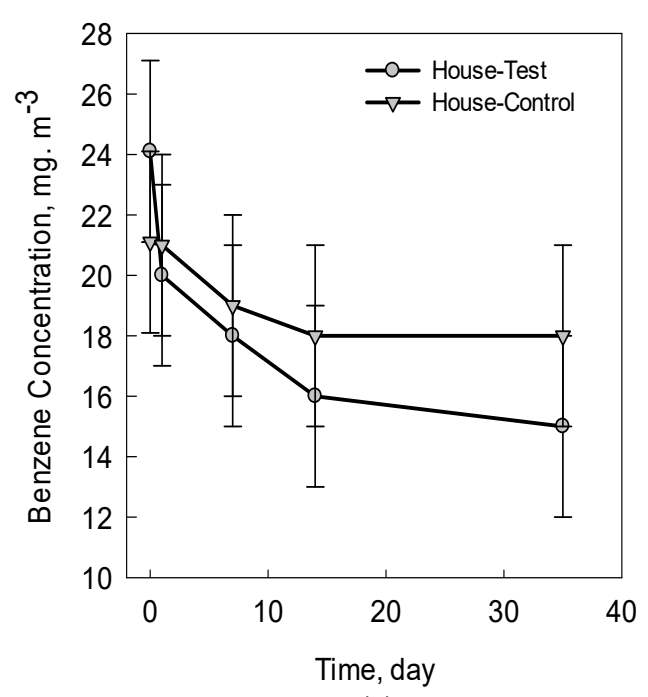

(a)

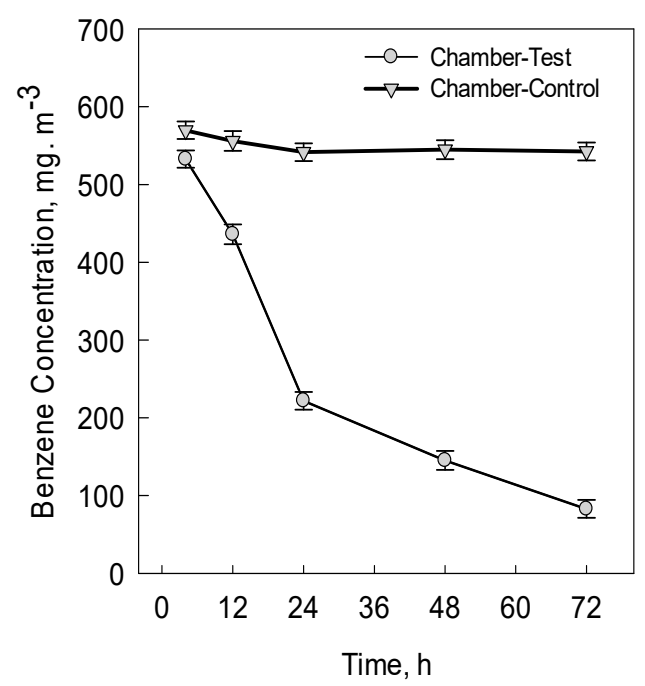

(b)

Figure 1. Benzene removal efficiency of Epipremnum aureum in house (a) and in chamber (b). The error bar indicates the standard deviation for three replicates.

Three C3 plants (Epipremnum aureum, Chlorophytum comosum, Hedera helix) and one CAM plant (Echinopsis tubiflora) were studied for their ability to remove benzene. As shown in Figure 2, the benzene removal efficiency of the four plants showed convergent trends over $72 \mathrm{~h}$. The final benzene removal efficiency of the four plants averaged 72 percent. The result indicates that benzene was taken up at a slightly faster rate by Epipremnum aureum than by the other three plants within $48 \mathrm{~h}$. The higher benzene removal efficiency of Epipremnum aureum is owing to high quantity of crude wax per leaf area and large number of stomata, which are the two important pathways for benzene absorption [18]. In this experiment, there was a significant difference in benzene removal efficiency among the three $\mathrm{C} 3$ plants with exposure from $12 \mathrm{~h}$ to $24 \mathrm{~h}(p<0.05)$. This difference implies that, under dark conditions (initial $12 \mathrm{~h}$ exposure), the stomata is closed, and the wax cuticles of plant leaves are the important pathway for the uptake of benzene $[18,25]$. 


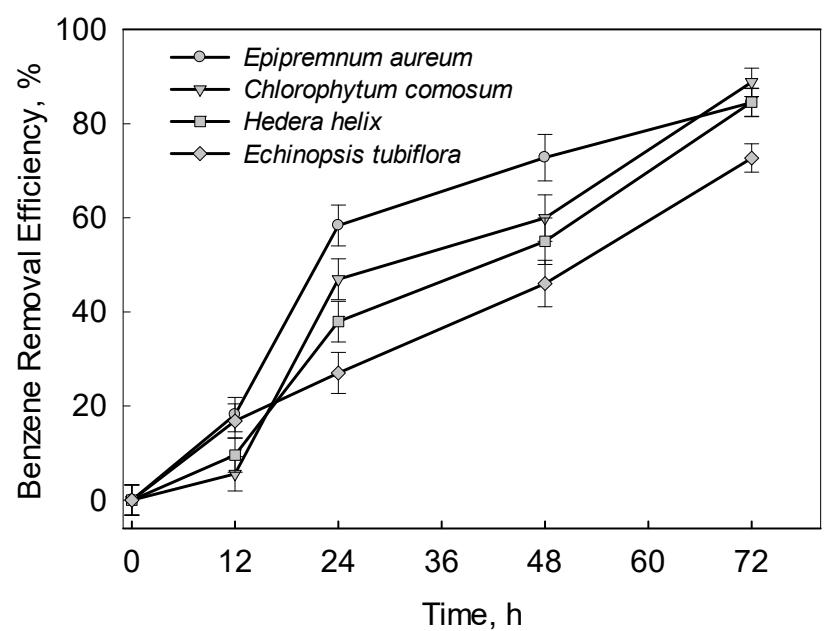

Figure 2. Benzene removal efficiency of Epipremnum aureum, Chlorophytum comosum, Hedera helix and Echinopsis tubiflora. The error bar indicates the standard deviation for three replicates.

As shown in Figure 3, the benzene absorption rate varied among the three plants (Epipremnum aureum, Chlorophytum comosum and Hedera helix). The benzene absorption rate of Epipremnum aureum $\left(1.10 \mu \mathrm{g} \cdot \mathrm{m}^{-3} \cdot \mathrm{cm}^{-2}\right)$ was the highest after $72 \mathrm{~h}$ of exposure, followed by Hedera helix $\left(0.85 \mu \mathrm{g} \cdot \mathrm{m}^{-3} \cdot \mathrm{cm}^{-2}\right)$ and Chlorophytum comosum $\left(0.27 \mu \mathrm{g} \cdot \mathrm{m}^{-3} \cdot \mathrm{cm}^{-2}\right)$. Under light conditions (exposure from $12 \mathrm{~h}$ to $24 \mathrm{~h}$ ), the plants' stomata were open; thus, much more benzene was absorbed through the stomata compared with dark conditions. On the other hand, there was a linear relationship between the benzene removal efficiency of Echinopsis tubiflora and exposure time. This can be attributed to the fact that Echinopsis tubiflora is a CAM plant, which can take up benzene by stomata under both light and dark conditions [26].

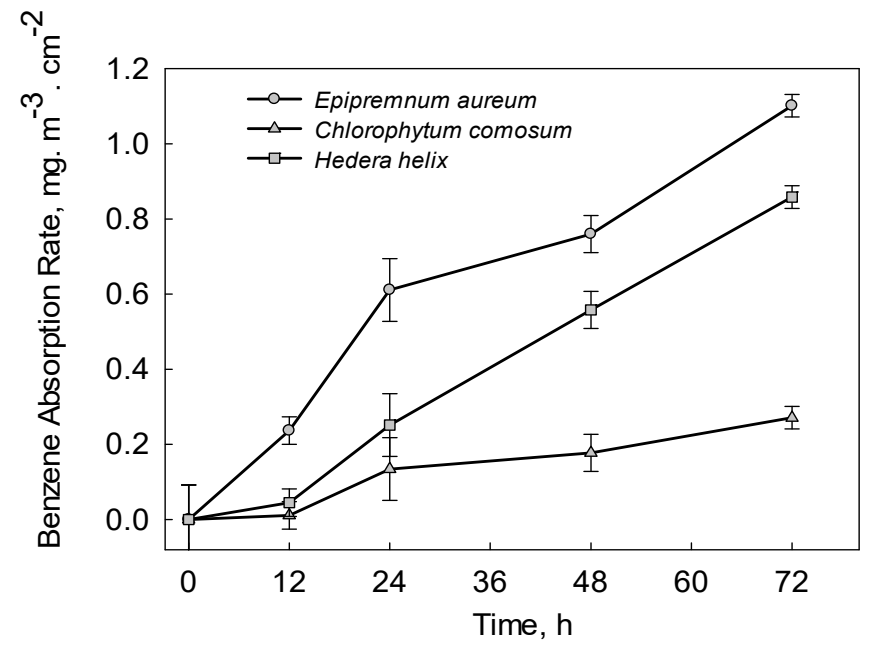

Figure 3. Benzene absorption rate of Epipremnum aureum, Chlorophytum comosum and Hedera helix. The error bar indicates the standard deviation for three replicates.

\subsection{Regulating Factors of Benzene Removal Efficiency}

\subsubsection{Chlorophyll Concentration, POD and Transpiration Rate}

As shown in Tables 1-3, the concentration of chlorophyll and rate of transpiration of the three screened plants decreased with exposure time, while the activity of POD of the three plants increased with exposure time. Chlorophyll concentration is used to determine the effects of stress factors on photosynthesis when the plant is exposed to adverse conditions [27]. After $72 \mathrm{~h}$ of fumigation, the 
chlorophyll concentrations of Epipremnum aureum, Chlorophytum comosum and Hedera helix decreased by $46.4 \%, 61.4 \%$ and $49.7 \%$, respectively. The results also showed significant differences in chlorophyll concentrations between the controlled plants and the treated plants (Epipremnum aureum, Chlorophytum comosum and Hedera helix) after being exposed to benzene for $72 \mathrm{~h}$. This is because VOCs cause chloroplasts to swell and damage them [26]. The result is consistent with previous studies which reported the negative effects of VOCs on the cell ultrastructure of plants [28].

Table 1. Chlorophyll concentration of the three plants under different exposure times.

\begin{tabular}{|c|c|c|c|c|c|}
\hline \multirow{2}{*}{ Plant Species } & \multicolumn{5}{|c|}{ Mean Concentration \pm S.D. $\left(\mathrm{mg} \cdot \mathrm{L}^{-1}\right)$} \\
\hline & $0 \mathrm{~h}$ & $12 \mathrm{~h}$ & $24 \mathrm{~h}$ & $48 \mathrm{~h}$ & $72 \mathrm{~h}$ \\
\hline Epipremnum Aureum & $38.63 \pm 0.05 b$ & $37.79 \pm 0.06 b$ & $32.93 \pm 0.05 a$ & $22.14 \pm 0.05 b$ & $20.71 \pm 0.07 b$ \\
\hline Chlorophytum Comosum & $28.06 \pm 0.07 c$ & $25.91 \pm 0.06 c$ & $20.32 \pm 0.04 c$ & $14.82 \pm 0.04 c$ & $10.82 \pm 0.05 c$ \\
\hline Hedera Helix & $44.84 \pm 0.08 \mathrm{a}$ & $38.16 \pm 0.05 a$ & $27.96 \pm 0.03 b$ & $24.37 \pm 0.07 a$ & $22.57 \pm 0.05 a$ \\
\hline
\end{tabular}

Note: the different letters in the same column indicate the significant difference among different plants at (Duncan test, $p<0.05)$.

Table 2. Peroxidase (POD) activity of the three plants under different exposure times.

\begin{tabular}{cccccc}
\hline \multirow{2}{*}{ Plant Species } & \multicolumn{5}{c}{ Mean Concentration \pm S.D.(U.(g·min) } \\
\cline { 2 - 6 } & $\mathbf{0 ~ h}$ & $\mathbf{1 2} \mathbf{~ h}$ & $\mathbf{2 4} \mathbf{~ h}$ & $\mathbf{4 8} \mathbf{~ h}$ & $\mathbf{7 2 ~} \mathbf{~ h}$ \\
\hline Epipremnum Aureum & $20.06 \pm 0.16 \mathrm{a}$ & $23.04 \pm 0.21 \mathrm{a}$ & $27.80 \pm 0.30 \mathrm{a}$ & $29.82 \pm 0.04 \mathrm{~b}$ & $36.44 \pm 0.06 \mathrm{a}$ \\
Chlorophytum Comosum & $16.39 \pm 0.23 \mathrm{c}$ & $17.90 \pm 0.20 \mathrm{c}$ & $19.75 \pm 0.20 \mathrm{~b}$ & $20.31 \pm 0.10 \mathrm{c}$ & $21.20 \pm 0.07 \mathrm{~b}$ \\
Hedera Helix & $18.44 \pm 0.14 \mathrm{~b}$ & $22.47 \pm 0.15 \mathrm{a}$ & $27.37 \pm 0.21 \mathrm{a}$ & $30.55 \pm 0.20 \mathrm{a}$ & $32.50 \pm 0.06 \mathrm{a}$ \\
\hline
\end{tabular}

Note: the different letters in the same column indicate the significant difference among different plants (Duncan test, $p<0.05)$.

Table 3. Transpiration rate of the three plants under different exposure times.

\begin{tabular}{cccccc}
\hline \multirow{2}{*}{ Plant Species } & \multicolumn{5}{c}{ Mean Concentration \pm S.D. $\mathbf{( 1 0 - 6 ~} \mathbf{g}^{-\mathbf{m}^{\mathbf{2}} \text { ) }}$} \\
\cline { 2 - 6 } & $\mathbf{0 ~ h}$ & $\mathbf{1 2} \mathbf{~ h}$ & $\mathbf{2 4} \mathbf{~ h}$ & $\mathbf{4 8} \mathbf{~ h}$ & $\mathbf{7 2} \mathbf{~ h}$ \\
\hline Epipremnum Aureum & $12.61 \pm 0.21 \mathrm{a}$ & $10.14 \pm 0.21 \mathrm{a}$ & $3.65 \pm 0.11 \mathrm{a}$ & $3.26 \pm 0.07 \mathrm{a}$ & $2.26 \pm 0.06 \mathrm{a}$ \\
Chlorophytum Comosum & $0.39 \pm 0.12 \mathrm{~b}$ & $0.38 \pm 0.11 \mathrm{~b}$ & $0.26 \pm 0.12 \mathrm{~b}$ & $0.25 \pm 0.14 \mathrm{~b}$ & $0.18 \pm 0.09 \mathrm{~b}$ \\
Hedera Helix & $0.24 \pm 0.13 \mathrm{~b}$ & $0.22 \pm 0.09 \mathrm{~b}$ & $0.18 \pm 0.11 \mathrm{~b}$ & $0.04 \pm 0.02 \mathrm{c}$ & $0.03 \pm 0.02 \mathrm{c}$ \\
\hline
\end{tabular}

Note: the different letters in the same column indicate the significant difference among different plants (Duncan test, $p<0.05)$.

After $72 \mathrm{~h}$ of fumigation, the POD activity of Epipremnum aureum, Chlorophytum comosum and Hedera helix increased by $81.6 \%, 29.3 \%$ and $76.2 \%$, respectively. The production and elimination of reactive oxygen types in plants were in dynamic balance under normal growth conditions. As exposure time increased in the experiment, the reactive oxygen types were over-accumulated. Therefore, the activity of POD was increased to eliminate reactive oxygen types [29].

After $72 \mathrm{~h}$ of fumigation, the transpiration rate of Epipremnum aureum, Chlorophytum comosum and Hedera helix decreased by $82.1 \%, 54.7 \%$ and $87.5 \%$, respectively. A higher rate of transpiration means higher stomatal conductivity. Jin et al. [30] reported that higher stomatal conductivity was the essential reason for the higher removal efficiency of volatile organic compounds. Our results show that Epipremnum aureum had a higher stomatal conductivity and benzene absorption rate than that of Chlorophytum comosum and Hedera helix, as shown in Figure 3.

As shown in Table 4, the concentration of chlorophyll and transpiration rate were significantly correlated with the benzene removal rate in Epipremnum aureum, Chlorophytum comosum and Hedera helix. Our results indicate that plants with a higher rate of transpiration and concentration of chlorophyll were more effective at removing benzene from indoor air. Although no significant correlation between 
POD activity and benzene removal rate was observed, there was a tendency for plants with lower POD activity to have a relatively high removal rate of benzene.

Table 4. Correlation coefficients between chlorophyll concentration, transpiration rate and POD activity, and benzene removal rate in different plants.

\begin{tabular}{cccc}
\hline Plant Species & Chlorophyll Concentration & Transpiration Rate & POD Activity \\
\hline Epipremnum Aureum & $0.901^{*}$ & $0.711^{*}$ & 0.469 \\
Chlorophytum Comosum & $0.751^{*}$ & $0.871^{*}$ & 0.420 \\
Hedera Helix & $0.875^{*}$ & $0.710^{*}$ & 0.481 \\
\hline
\end{tabular}

\subsubsection{Effect of Light Conditions}

Epipremnum aureum and Echinopsis tubiflora, the two plants with the greatest benzene removal efficiency in this study, were chosen to represent C 3 and CAM plants in this study. The plants were held in a fumigation chamber containing $0.2 \mathrm{ppm}$ of benzene for $24 \mathrm{~h}$ under light, dark, and normal conditions, respectively. The results show that the benzene removal efficiency of Epipremnum aureum under light conditions (68\%) was higher, compared with that under normal $(55 \%)$ or dark conditions (35\%) (Figure $4 \mathrm{~b}$ ). However, no significant difference in the benzene removal efficiency of Echinopsis tubiflora was observed under different light conditions (Figure 4a). It has been reported that the stomata are an important pathway for the uptake of VOCs [31]. Stomata are usually closed when leaves are transferred from light to darkness. However, stomatal openness in succulent plants or CAM plants under dark conditions has been observed [32]. Therefore, light or dark conditions had little effect on the benzene removal efficiency of Echinopsis tubiflora, the CAM plant in this study.

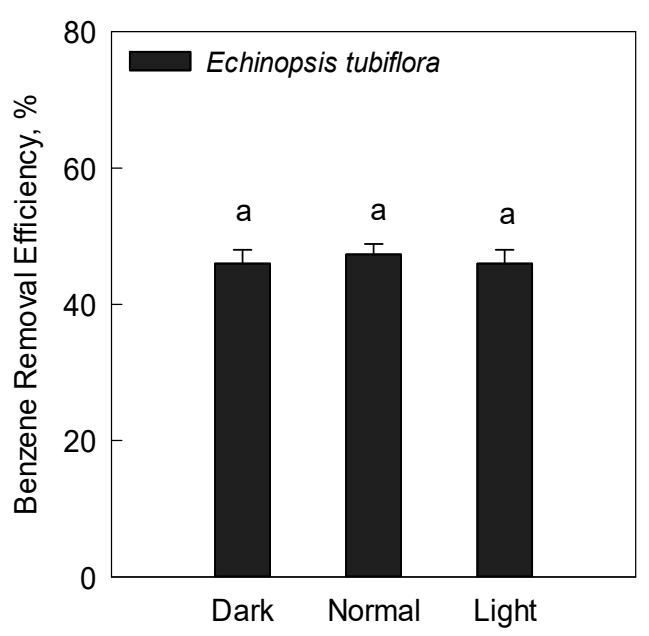

(a)

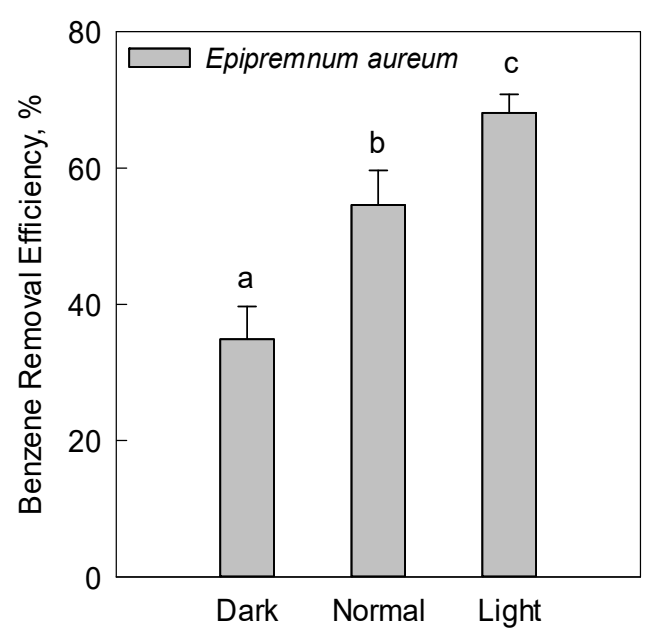

(b)

Figure 4. Benzene removal efficiency of Echinopsis tubiflora (a) and Epipremnum aureum (b) under normal conditions ( $12 \mathrm{~h}$ light and $12 \mathrm{~h}$ dark), light conditions ( $24 \mathrm{~h}$ light), and dark conditions ( $24 \mathrm{~h}$ dark). The error bar indicates the standard deviation for three replicates. The different letters above columns indicate the significant difference under different light conditions (Duncan test, $p<0.05$ ).

\subsubsection{Effect of Benzene Concentration}

As shown in Figure 5, the benzene removal efficiency of the four plants varied between different benzene concentrations. When the initial concentration of benzene increased from $0.2 \mathrm{ppm}$ to $50 \mathrm{ppm}$, the benzene removal efficiency of Epipremnum aureum, Chlorophytum comosum, Hedera helix and Echinopsis tubiflora decreased by $31.3 \%, 42.4 \%, 28.4 \%$ and $46.9 \%$, respectively. This can be attributed to the fact that high concentrations of VOC vapors cause chloroplasts to swell and damage them [26]. The high 
benzene removal efficiency of Epipremnum aureum under low or high levels of benzene can be ascribed to its high rate of transpiration and concentration of chlorophyll.

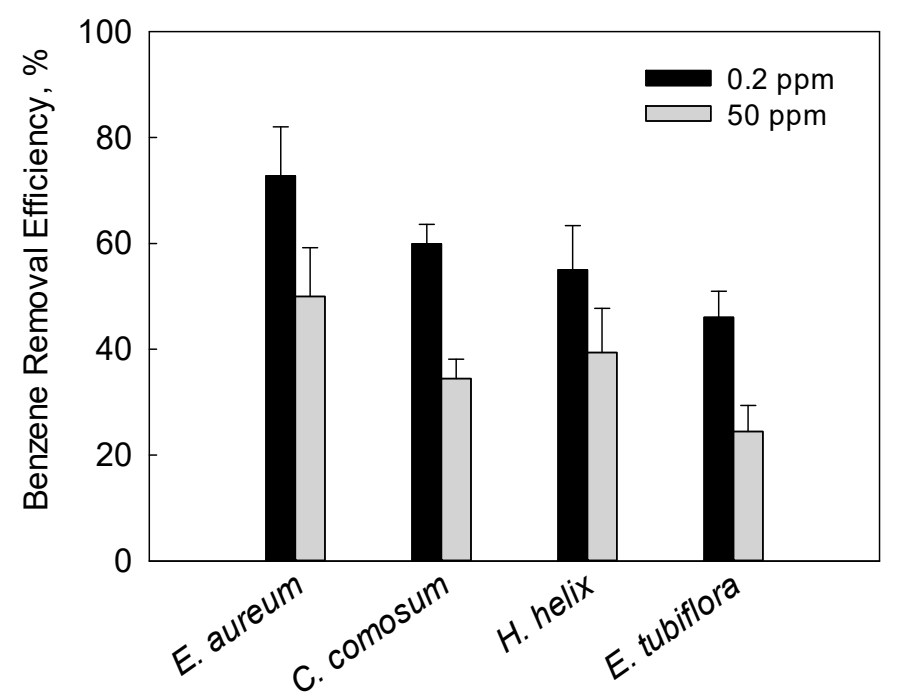

Figure 5. Comparison of benzene removal efficiency of the four plants after being exposed to $0.2 \mathrm{ppm}$ and $50 \mathrm{ppm}$ of benzene. The error bar indicates the standard deviation for three replicates.

\section{Conclusion}

Epipremnum aureum, Chlorophytum comosum, Hedera helix and Echinopsis tubiflora could all be chosen to reduce the concentration of benzene in indoor air. They could remove about $72 \%$ of benzene over $72 \mathrm{~h}$. The properties of each plant, light conditions and different concentrations of benzene affected the benzene removal efficiency. The higher the rate of transpiration and chlorophyll concentration of the plant, the greater the efficiency of the plant to remove benzene from indoor air. There was no significant removal efficiency difference of Echinopsis tubiflora under different light conditions. This is due to the fact that its stomata remain open regardless of light conditions. In this study, the relatively high benzene removal efficiency under high benzene concentration is attributed to the high rate of transpiration and concentration of chlorophyll. Our findings indicate that transpiration rate and chlorophyll concentration can be used as reference parameters to facilitate the screening of ornamental plants for indoor air quality improvement. In addition, compared with C3 plants (Epipremnum aureum, Chlorophytum comosum, Hedera helix), CAM plants (Echinopsis tubiflora) are more effective at removing benzene from indoor air. Given that benzene is not the only pollutant in indoor air, further research should focus on the fundamentals of ornamental plants in removing other indoor air pollutants.

Author Contributions: For research articles with several authors, a short paragraph specifying their individual contributions must be provided. The following statements should be used "Conceptualization, B.X.; Methodology, T.Z., P.W., Y.L., R.Z. and Y.Z.; Software, Y.G.; Formal Analysis, Y.G.; Resources, T.Z. and Y.Z.; Data Curation, Y.G., P.W., Y.L. and R.Z.; Writing-Original Draft Preparation, Y.G.; Writing-Review \& Editing, B.X.; Supervision, B.X.; Project Administration, B.X.; Funding Acquisition, B.X.", please turn to the CRediT taxonomy for the term explanation. Authorship must be limited to those who have contributed substantially to the work reported.

Funding: This research was supported by the National Key R\&D Program of China (Grant No. 2018YFC1901400) and the Shanghai Institute of Pollution Control and Ecological Security.

Acknowledgments: This material was based on the work partially sponsored by National Key R\&D Program of China (Grant No. 2018YFC1901400) and the Shanghai Institute of Pollution Control and Ecological Security. The authors would like to thank China Scholarship Council for the scholarship.

Conflicts of Interest: The author(s) declared no potential conflict of interest with respect to the research, authorship and/or publication of this article. 


\section{References}

1. Rinsky, R.A. Benzene and leukemia an epidemiological risk assessment. Environ. Health Perspect. 1989, 82, 189-191. [CrossRef]

2. Schnatter, A.R.; Rosamilia, K.; Wojcik, N.C. Review of the literature on benzene exposure and leukemia subtypes. Chem. Biol. Interact. 2005, 153, 9-21. [CrossRef]

3. Klepeis, N.E.; Nelson, W.C.; Ott, W.R.; Robinson, J.P.; Tsang, A.M.; Switzer, P.; Behar, J.V. The national human activity pattern survey (nhaps): A resource for assessing exposure to environmental pollutants. J. Expo. Anal. Environ. Epidemiol. 2001, 11, 231-252. [CrossRef]

4. Yu, B.F.; Hu, Z.B.; Liu, M.; Yang, H.L.; Kong, Q.X.; Liu, Y.H. Review of research on air-conditioning systems and indoor air quality control for human health. Int. J. Refrig. 2009, 32, 3-20. [CrossRef]

5. Guieysse, B.; Hort, C.; Platel, V.; Munoz, R.; Ondarts, M.; Revah, S. Biological treatment of indoor air for VOC removal: Potential and challenges. Biotechnol. Adv. 2008, 26, 398-410. [CrossRef] [PubMed]

6. Wolverton, B.C.; McDonald, R.C.; Watkins, E. Foliage plants for removing indoor air pollutants from energy-efficient homes. Econ. Bot. 1984, 38, 224-228. [CrossRef]

7. Godish, T.; Guindon, C. An assessment of botanical air purification as a formaldehyde mitigation measure under dynamic laboratory chamber conditions. Environ. Pollut. 1989, 62, 13-20. [CrossRef]

8. Dela Cruz, M.; Christensen, J.H.; Thomsen, J.D.; Muller, R. Can ornamental potted plants remove volatile organic compounds from indoor air? A review. Environ. Sci. Pollut. Res. Int. 2014, 21, 13909-13928. [CrossRef] [PubMed]

9. Abbass, O.A.; Sailor, D.J.; Gall, E.T. Effectiveness of indoor plants for passive removal of indoor ozone. Build. Environ. 2017, 119, 62-70. [CrossRef]

10. Dela Cruz, M.; Muller, R.; Svensmark, B.; Pedersen, J.S.; Christensen, J.H. Assessment of volatile organic compound removal by indoor plants-A novel experimental setup. Environ. Sci. Pollut. Res. Int. 2014, 21, 7838-7846. [CrossRef]

11. Orwell, R.L.; Wood, R.L.; Tarran, J.; Torpy, F.; Burchett, M.D. Removal of benzene by the indoor plant/substrate microcosm and implications for air quality. Water Air Soil Pollut. 2004, 82, 189-191. [CrossRef]

12. Yoo, M.H.; Kwon, Y.J.; Son, K.; Kays, S.J. Efficacy of indoor plants for the removal of single and mixed volatile organic pollutants and physiological effects of the volatiles on the plants. J. Am. Soc. Hortic. Sci. 2006, 131, 452-458. [CrossRef]

13. Liu, Y.-J.; Mu, Y.-J.; Zhu, Y.-G.; Ding, H.; Crystal Arens, N. Which ornamental plant species effectively remove benzene from indoor air? Atmos. Environ. 2007, 41, 650-654. [CrossRef]

14. Yang, D.S.; Pennisi, S.V.; Son, K.C.; Kays, S.J. Screening indoor plants for volatile organic pollutant removal efficiency. HortScience 2009, 44, 1377-1381. [CrossRef]

15. Chun, S.C.; Yoo, M.H.; Moon, Y.S.; Shin, M.H.; Son, K.C.; Chung, I.M.; Kays, S. Effect of bacterial population from rhizosphere of various foliage plants on removal of indoor volatile organic compounds. Korean J. Hortic. Sci. Technol. 2010, 28, 476-483.

16. Sriprapat, W.; Thiravetyan, P. Phytoremediation of BTEX from indoor air by Zamioculcas zamiifolia. Water Air Soil Pollut. 2013, 224, 1482. [CrossRef]

17. Wood, R.A.; Burchett, M.D.; Alquezar, R.; Orwell, R.L.; Tarran, J.; Torpy, F. The potted-plant microcosm substantially reduces indoor air voc pollution: I. Office field-study. Water Air Soil Pollut. 2006, 175, 163-180. [CrossRef]

18. Treesubsuntorn, C.; Thiravetyan, P. Removal of benzene from indoor air by Dracaena sanderiana: Effect of wax and stomata. Atmos. Environ. 2012, 57, 317-321. [CrossRef]

19. Irga, P.J.; Torpy, F.R.; Burchett, M.D. Can hydroculture be used to enhance the performance of indoor plants for the removal of air pollutants? Atmos. Environ. 2013, 77, 267-271. [CrossRef]

20. Weyens, N.; Thijs, S.; Popek, R.; Witters, N.; Przybysz, A.; Espenshade, J.; Gawronska, H.; Vangronsveld, J.; Gawronski, S.W. The role of plant-microbe interactions and their exploitation for phytoremediation of air pollutants. Int. J. Mol. Sci. 2015, 16, 25576-25604. [CrossRef]

21. Nelson, M.; Wolverton, B.C. Plants+soil/wetland microbes: Food crop systems that also clean air and water. Adv. Space Res. 2011, 47, 582-590. [CrossRef] 
22. Giese, M.; Bauerdoranth, U.; Langebartels, C.; Sander-mann, H. Detoxification of formaldehyde by the spider plant (Chlorophytum comosum L.) and by soybean (Glycine max L.) cell-suspension cultures. J. Plant Physiol. 1994, 104, 1301-1309. [CrossRef]

23. Biddington, N.; Thomas, T.H. Influence of different cytokinins on the transpiration and senescence of excised oat leaves. Physiol. Plant. 1987, 42, 369-374. [CrossRef]

24. Lim, Y.W.; Kim, H.H.; Yang, J.Y.; Kim, K.J.; Lee, J.Y.; Shin, D.C. Improvement of indoor air quality by houseplants in new-built apartment buildings. Hortc. J. 2009, 78, 456-462. [CrossRef]

25. Kvesitadze, E.; Sadunishvili, T.; Kvesitadze, G. Mechanisms of organic contaminants uptake and degradation in plants. Int. J. Biol. Biomol. Agric. Food Biotechnol. Eng. 2009, 3, 361-371.

26. Sriprapat, W.; Boraphech, P.; Thiravetyan, P. Factors affecting xylene-contaminated air removal by the ornamental plant Zamioculcas zamiifolia. Environ. Sci. Pollut. Res. Int. 2014, 21, 2603-2610. [CrossRef]

27. Maxwell, K.; Johnson, G.N. Chlorophyll fluorescence-A practical guide. J. Exp. Bot. 2000, 51, $659-668$. [CrossRef]

28. Sadunishvili, T.; Kvesitadze, E.; Betsiashvili, M.; Kuprava, N.; Zaalishvili, G.; Kvesitadze, G. Influence of hydrocarbons on plant cell ultrastructure and main metabolic enzymes. World Acad. Sci. Eng. Technol. 2009, 3, 271-276.

29. Takahama, U.; Oniki, T. A peroxidase/phenolics/ascorbate system can scavenge hydrogen peroxide in plant cells. J. Plant Physiol. 1997, 101, 845-852. [CrossRef]

30. Jin, C.J.; Zhou, X.J.; Zhao, H.T.; Liu, X.M.; Feng, K. Comparison of removal of formaldehyde capacity between Hedera helix and Melissa officinalis. Asian J. Chem. 2013, 25, 3823-3826. [CrossRef]

31. Collins, C.; Fryer, M.; Grosso, A. Plant uptake of non-ionic organic chemicals. Environ. Sci. Technol. 2006, 40, 45-52. [CrossRef] [PubMed]

32. Lee, J.S. Stomatal opening mechanism of CAM plants. J. Plant Biol. 2010, 53, 19-23. [CrossRef]

(C) 2019 by the authors. Licensee MDPI, Basel, Switzerland. This article is an open access article distributed under the terms and conditions of the Creative Commons Attribution (CC BY) license (http://creativecommons.org/licenses/by/4.0/). 